\title{
KAJIAN FILOSOFIS PEMBELAJARAN DARING PENDIDIKAN VOKASI DI ERA PANDEMI COVID-19: ANALISIS FUNGSIONAL SARANA PEMBELAJARAN DARING TERHADAP ESENSI PEMBELAJARAN
}

\author{
Dhega Febiharsa, Djoko Kustono \\ Universitas Ivet, Universitas Negeri Malang \\ febiharsa@gmail.com
}

\begin{abstract}
ABSTRAK
Pandemi Covid-19 telah mengubah sistem pembelajaran secara signifikan, dari tatap muka menjadi belajar di rumah. Suatu keadaan dimana memaksa guru dan murid harus melaksanakan pembelajaran jarak jauh dan terbatas. Berbagai sarana pembelajaran daring dengan berbagai kelebihan dan kekurangannya dimanfaatkan untuk tetap melaksanakan kegiatan belajar mengajar secara daring. Fenomena ini menarik peneliti untuk melakukan kajian terhadap kaidah pembelajaran dari, fasilitas pembelajaran daring dan menghubungkannya dengan makna pembelajaran secara filosofis. Studi literatur digunakan untuk mendapatkan teori-teori yang mendukung kajian yang dilakukan. Selanjutnya peneliti mengidentifikasi layanan atau fasilitas pembelajaran daring dari sisi filosofis atas aktivitas atau interaksi guru dan siswa dengan sarana pembelajaran daring tersebut. Dari kajian dan identifikasi yang dilakukan didapatkan bahwa sebagian besar sarana pembelajran daring tersebut secara filosofis telah mewakili konsep atau esensi dari pembelajaran secara kualitatif. Kata kunci: kajian filosofis, pembelajaran daring, pendidikan vokasi, esensi pembelajaran.
\end{abstract}

\begin{abstract}
The Covid-19 pandemic has significantly changed the learning system, from face-to-face to home learning. A situation where forcing teachers and students to carry out distance learning and is limited. Various online learning tools with various advantages and disadvantages are utilized to continue carrying out teaching and learning activities online. This phenomenon attracts researchers to study the principles of learning from online learning facilities and relate them to the philosophical meaning of learning. Literature studies are used to obtain theories that support the studies conducted. Furthermore, the researcher identifies online learning services or facilities from a philosophical point of view of the activities or interactions of teachers and students with these online learning tools. From the study and identification conducted, it was found that most of the online learning tools have philosophically represented the concept or essence of learning qualitatively. Keywords: Philosophical studies, online learning, vocational education, the essence of learning.
\end{abstract}

\section{PENDAHULUAN}

Pandemi Covid-19 memaksa pembelajaran harus dilaksanakan secara daring guna mencegah penyebaran virus corona (covid-19). Semua Lembaga Pendidikan menerapkan sistem belajar daring dan bekerja dari rumah sesuai instruksi Menteri Pendidikan dan Kebudayaan dengan Surat Edaran Menteri Pendidikan dan Kebudayaan Nomor 36962/MPK.A/HK/
2020 tentang Pembelajaran secara Daring dan Bekerja dari Rumah dalam rangka pencegahan Penyebaran Corona Virus Desease (Covid-19). Pada surat edaran tersebut Menteri Pendidikan dan Kebudayaan menginstruksikan untuk memberlakukan pembelajaran secara daring dari rumah bagi siswa dan mahasiswa. Pemerintah menyediakan sarana pembelajaran daring secara gratis melalui 
layanan daring Rumah Belajar, Google $G$ Suite for Education, Kelas Pintar, Microsoft Office 365, Quipper School, Sekolah Online Ruang Guru, Sekolahmu, dan Zenius (Kementerian Pendidikan dan Kebudayaan Republik Indonesia, 2020).

Penerapan pembelajaran daring ini memaksa para guru, dosen, dan manajemen sekolah dan manajemen perguruan tinggi untuk mengubah sistem pembelajaran dari yang semula tatap muka menjadi daring. Demikian halnya para orang tua, harus menyediakan fasilitas akses internet untuk anak-anaknya. Pada implementasinya, orang tua dilibatkan secara penuh untuk mengawal pembelajaran di rumah untuk anak didik usia dini, dan sekolah dasar. Di sini peran orang tua menjadi lebih besar dalam pembelajaran di rumah khususnya Anak Usia Dini. Guru dan Dosen menjadi fasilitator dalam proses pembelajaran. Hal yang menjadi kendala utama pada system pembelajaran daring ini adalah pada mata pelajaran atau mata kuliah praktek, khsusunya di Pendidikan vokasi atau kejuruan.

Di Pendidikan vokasi, praktikum adalah hal yang tidak bisa dihindari, dalam pembelajaran daring praktikum sangat sulit dilakukan untuk mata pelajaran atau mata kuliah dengan sarana praktik yang membutuhkan alat atau bahan yang tidak dimiliki oleh siswa atau mahasiswa secara individu. Beberapa mata praktik tidak dapat dilakukan secara daring, sehingga tatap muka tidak dapat dihindari dengan menerapkan protokol kesehatan yang telah ditetapkan oleh pemerintah. Metode yang digunakan dalam penelitian ini adalah literature review, yang akan mengkasi implementasi pembelajaran daring yang popular digunakan, dan dikatikan dengan esensi secara filosofis untuk memberi gambaran hubungan antara pembelajaran yang dilaksanakan dengan filsafat ilmu di bidang pendidikan kejuruan.

\section{METODE}

Penelitian ini menggunakan metode studi literatur, kemudian dilakukan observasi fitur-fitur dan fasilitas pembelajaran daring dihubungkan dengan kaidah filosofis yang diidentifikasi dalam suatu proses pembelajaran daring secara teknis dan substansi dari aktivitas yang dilakukan oleh guru/ dosen dan siswa/ mahasiswa saat melakukan pembelajaran daring.

\section{KAJIAN TEORI Pembelajran dari Rumah di Masa Pandemi Covid-19 dan Strateginya}

Sebagaimanan disebutkan dalam Pedoman Pelaksanaan Belajar dari Rumah Kementerian Pendidikan dan Kebudayaan Republik Indonesia, metode pelaksanaan belajar dari rumah (BDR) terbagi menjadi dua, yaitu: (1) Pembelajaran jarak jauh dalam jaringan/ online (daring) merupakan pembelajaran dengan menggunakan perangkat smartphone (gadget) maupun laptop melalui beberapa website dan aplikasi pembelajaran daring; dan (2) Pembelajaran jarak jauh luar jaringan/ offline (luring), menggunakan media televisi, radio, modul belajar mandiri dan lembar kerja, bahan ajar cetak, alat peraga dan media belajar dari benda di lingkungan sekitar. Dalam pedoman tersebut juga disebutkan bahwa peran Pendidik (guru/ dosen) adalah memfasilitasi pembelajaran jarak jauh secara daring, luring maupun kombinasi keduanya sesuai dengan kondisi dan ketersediaan sarana pembelajaran (Kemendikbud, 2020).

Adapun strategi dalam pembelajran daring meliputi strategi untuk pendidik dan strategi untuk peserta didik, serta peran orang tua dalam pembelajaran dari rumah. Pada pembelajaran luring, fasilitator dalam hal ini guru/ dosen (dan orang tua untuk Pendidikan dasar) melaksanakan prosedur-prosedur pada tiap tahap pembelajaran. Pada tahap PraPembelajaran, guru harus: (1) menyiapkan rencana pembelajaran, (2) media 
pembelajaran atau bahan ajar, jadwal, dan lembar penugasan untuk dikirim ke peserta didik/ orang tua/ wali; (3) memastikan semua peserta didik memperoleh jadwal dan penugasan yang dapat diambil atau diberikan setiap minggu melalui media komunikasi yang tersedia; (4) Guru dan orang tua/ wali peserta didik yang bertemu langsung untuk mengambil jadwal dan penugasan wajib mematuhi protokol kesehatan. Sedangkan pada tahap pembelajaran mekanisme yang harus dilalui adalah: (1) Pembelajaran luring dibantu orang tua/ wali peserta didik sesuai jadwal dan penugasan yang diberikan; (2) guru dapat melakukan kunjungan ke rumah (home visit) ke peserta didik untuk memeriksa (pengecekan) dan pendampingan belajar dengan menerapkan protokol kesehatan; (3) berdoa bersama sebelum dan sesudah belajar. Kemudian pada tahap akhir pembelajaran: (1) peserta didik mengisi lembar aktivitas sebagai sarana pemantauan belajar harian; (2) orang tua/ wali memberikan tendatangan pada tiap sesi belajar yang telah tuntas; (3) penugasan diberikan sesuai jadwal; (4) muatan penugasan adalah pendidikan kecakapan hidup, diantaranya tentang covid-19, konten rekreasional, ajakan menjaga kesehatan, baik itu mental maupun fisik; (5) hasil penugasan dan lembar pemantauan aktivitas dikumpulkan setiap minggu, sekaligus mengambil jadwal dan penugasan berikutnya, atau hal ini dapat dilakukan dengan sarana komunikasi elektronik seperti WhatsApp, Email dan sebagainya (Kemendikbud, 2020).

Pada Pendidikan vokasi yang menuntut keterampilan kognitif, afektif, dan psikomotorik, pembelajaran luring dengan protocol kesehatan tetap dapat dilakukan berdasarkan pedoman BDR Kemdikbud. Namun pada kenyataanya tidak sedikit sekolah yang tidak mau ambil resiko dengan melaksanakan pembelajaran luring.
Berdasarkan Panduan Praktis Pembelajaran SMK di Masa Kebiasaan Baru Direktorat Pembinaan SMK, diberlakukan sistem pembelajaran tatap muka dengan protocol kesehatan dan belajar dari rumah. Pembelajran praktik yang tidak dapat dilakukan secara dari rumah, dilaksanakan secara tatap muka atau di IDUKA (Industri, Dunia Usaha, dan Dunia Kerja) dengan tetap menerapkan protokol kesehatan. Pembelajaran praktik yang tidak dapat dilakukan sesuai dengan jadwal baik tatap muka maupun BDR dapat dilaksanakan secara blok pada akhir semester, dengan tetap menerapkan protokol kesehatan. Pengawasan terhadap pelaksanaan praktikum dilakukan sekolah untuk memastikan keterlibatan peserta didik baik secara tatap muka maupun BDR (Direktorat et al., 2020).

Pada panduan pelaksanaan BDR juga menekankan sisi humanis, yang secara filosofis memberikan pemahaman bagaimana peserta didik berinteraksi dalam situasi dan kondisi pandemi.

\section{Filosofi Pendidikan di Era Digital}

Teori belajar dimaksudkan untuk menjelaskan dan membantu kita memahami bagaimana orang belajar; Ini melibatkan berbagai disiplin ilmu, termasuk psikologi, sosiologi, ilmu saraf, dan tentu saja, pendidikan. Tiga dari teori pembelajaran yang lebih populer diantaranya: behaviorisme, kognitivisme, dan konstruktivisme sosial (Picciano, 2017). Socrates dan keturunannya telah lama menginformasikan pandangan pendidikan harus menumbuhkan pada semua siswa, sejauh mungkin, disposisi untuk mencari alasan dan kemampuan untuk mengevaluasinya secara meyakinkan, dan untuk dibimbing oleh evaluasi mereka dalam masalah kepercayaan, tindakan dan penilaian. Pandangan ini, bahwa pendidikan secara terpusat melibatkan pengembangan nalar atau rasionalitas, dengan artikulasi dan 
kualifikasi yang berbeda-beda telah dianut oleh sebagian besar tokoh tersebut (Siegel, Harvey, D.C. Phillips, 2018).

Era Digital mengubah paradigma Pendidikan, dimana pendidikan tak lagi harus dilakukan secara langsung atau tatap muka, perkembangan teknologi mentransformasi proses Pendidikan menjadi lebih bervariasi, inovatif, dan lebih mudah. Janji bahwa pendidikan digital akan merevolusi pengajaran dan pembelajaran melalui, misalnya, ketersediaan luas sumber daya pembelajaran digital atau pengalaman belajar virtual yang direstrukturisasi secara radikal, sering kali berlalu tanpa mengomentari asumsi sosial, etika, dan epistemik yang mendasari perubahan tersebut. Dengan munculnya Massive Onpen Online Course (MOOC) dan dampak berkelanjutan dari teknologi pada budaya pendidikan, hal ini memberi gambaran atas perubahan berkelanjutan yang nampak di dunia sekitar kita. Tingkatan yang berbeda di mana teknologi digital memeriksa dari data primer biner, melalui algoritma dan platform perangkat lunak, hingga dampak sosiomaterial teknologi di kelas dan masyarakat luas. Teknologi ini menjadi agenda menarik untuk penelitian masa depan yang membawa bersama-sama kepekaan teknis, normatif dan pedagogis untuk mengatasi fenomena pedagogi manusia yang unik (Lewin \& Lundie, 2016).

Di era digital, pembelajaran ditransformasi ke bentuk digital seperti halnya online text, laman web, dokumen PDF, Video, Audio, dan bentuk digital lainnya, dan dikirim kepada peserta didik melalui jalur transmisi digital. Menurut Bailenson, dkk (2008), transformasi digital melalui media dapat meningkatkan pembelajaran siswa dalam beberapa konteks. Tentu saja, tidak semua siswa di seluruh dunia akan mengenakan Head Mounted Diplay (HMD) kapan pun dalam waktu dekat; namun, kemungkinan menggunakan jenis media digital lain seperti video game, halaman Web, dan lain-lain, semakin meningkat.

\section{Guru/ Dosen sebagai Fasilitator}

Guru adalah faktor terpenting dalam pembangunan bangsa. Siswa adalah kekayaan negara kita. Sumber daya manusia yang kompeten, berpengetahuan luas, terampil harus dididik oleh guru oleh karena itu guru harus berpikir positif tentang hal tersebut. Terlebih di era sekarang yang merupakan era global. Berbagai perubahan dan tren baru sedang datang di bidang Pendidikan. Sekarang guru berperan sebagai fasilitator dalam pembelajaran. Mengajar dan belajar sedang dimodifikasi karena inovasi dalam Pendidikan. Guru akan sadar sebagai fasilitator, guru akan menggunakan metodologi pembelajaran aktif, teknik pembelajaran aktif di kelas, pembelajaran berbasis proyek. Guru akan mengetahui peran fasilitator, dan guru akan meningkatkan kualitas fasilitator sebagai guru. Guru akan memikirkan poin fasilitator dari pandangan. Guru akan menggunakan strategi pengajaran baru dalam proses belajar mengajar.. (Jagtap, 2016). Guru dapat menggunakan model pembelajaran bersama, dengan berdiskusi dengan peserta didik, dimana guru mengubah peran dalam situasi tertentu untuk menciptakan lebih banyak kesempatan bagi peserta didik pada pembelajaran di luar ruangan (Outdoor Education) (Thomas, 2010).

Peran guru atau dosen sebagai fasilitator yang mengawal peserta didik untuk mendapatkan ilmu pengetahuan, dengan mengawal siswa/ mahasiswa untuk mendapatkan informasi yang tepat dan terarah tentang suatu hal dari berbagai sumber. Memberi umpan balik Umpan balik terkait dengan evaluasi formatif untuk peningkatan kinerja dianggap efektif dalam literatur. Namun, dapat dikatakan bahwa alasan utama umpan balik untuk membantu 
pelajar memaksimalkan potensi mereka di berbagai tahapan pelatihan, tingkatkan kesadaran mereka kekuatan dan area untuk perbaikan, dan mengidentifikasi tindakan (Srivastava, 2014).

\section{Pembelajaran Sepanjang Hayat}

Pendidikan Sepanjang Hayat merupakan konsep dimana proses pendidikan dapat dilakukan kapan pun dan dimana pun tanpa batasan usia, ruang dan waktu. Konsep ini bermakna bahwa pendidikan bisa didapatkan dalam kehidupan manusia mulai lahir hingga akhir hayat. Pengetahuan, keterampilan hingga pengalaman pada hakekatnya bisa didapatkan dimanapun, kapanpun dan dari siapapun. Pelajaran bisa didapatkan dari pengalaman kehidupan sehari-hari. Pendidikan sepanjang hayat ini bertujuan untuk mengembangkan potensi manusia seoptimal mungkin, dan untuk menyelaraskan program pendidikan wajib belajar dengan proses pengembangan kepribadian manusia yang dinamis (Wikipedia, 2020b). Manfaat terbesar dari pembelajaran sepanjang hayat yaitu: (1) manfaat membantu kita beradaptasi dengan perubahan. Seorang pembelajar seumur hidup akan mengikuti masyarakat dengan tetap tinggal saat ini dan menyadari perubahan di berbagai bidang seperti teknologi, berita dan tren politik atau masalah keuangan dan keuangan; (2) kesempatan untuk memperoleh pendapatan atau penghasilan lebih besar; (3) manfaat besar pembelajaran sepanjang hayat adalah memperkaya dan memenuhi kehidupan, dengan kata lain kehidupan sesorang akan jauh lebih bermakna. Orang-orang yang melanjutkan pendidikan menjadi kodrat kedua, mereka dapat menantikan kehidupan yang aktif dan bermakna daripada bertahuntahun duduk-duduk dan menyaksikan kehidupan berlalu begitu saja. Seorang pembelajar seumur hidup menggunakan kesempatan untuk menjelajahi topik yang menurut mereka menarik (Laal \& Salamati, 2012).

\section{Prinsip Pendidikan Formal, Non-Formal, dan Informal}

Pendidikan dipandang sebagai kunci pembangunan berkelanjutan. Perdebatan tentang pertumbuhan dan daya saing menyoroti peran sentral yang diberikan pada sistem pendidikan dan pendidikan, pembelajaran formal, non-formal dan informal untuk memastikan jalur pembangunan ekonomi dan kohesi atau kesesuaian dan ketersambungan sosial yang berkelanjutan. Pendidikan dituntut untuk mempersiapkan peserta didik untuk berintegrasi secara efektif dalam lingkungan sosioal-profesional, untuk memiliki delapan kompetensi utama yang akan meyakinkan dunia usaha atau industri. Menurut pendapat para pakar, keberhasilan di pasar tenaga kerja, adalah salah satu argumen kunci yang mendukung pentingnya pembelajaran formal, berkorelasi dengan pembelajaran nonformal dan informal (Tudor, 2013).

\section{HASIL DAN PEMBAHASAN Pembelajaran Sinkronus dengan Video Conference}

Tatap muka secara daring dapat dilakukan dengan fasilitas Video Converence (Vicon), namun kelemahan dari video conference dalam pembelajaran di Indonesia, adalah jaringan dan kebutuhan data yang cukup tinggi. Vicon atau Konferensi Video adalah seperangkat teknologi telekomunikasi interaktif yang memungkinkankan dua pihak atau lebih di lokasi berbeda dapat berinteraksi melalui pengiriman dua arah audio dan video secara bersamaan. Sarana ini memberikan kesempatan kepada siswa untuk belajar dengan berpartisipasi dalam bentuk komunikasi video dua arah. Siswa mampu mengeksplorasi, berkomunikasi, menganalisis, dan berbagi informasi dan ide dengan satu sama lain (Wikipedia, 2020a). Dengan 
menggunakan vicon guru dan siswa dapat berinteraksi langsung melalui tayangan video saat yang bersamaan (sinkronus). Namun membutuhkan keterampilan khusus dalam pengoperasiannya. Untuk melakukan vicon, Guru maupun Siswa membutuhkan aplikasi vicon dan jaringan internet yang stabil serta didukung dengan paket data internet sekitar 1 Gigabytes (GB) untuk melakukan video conference 25-30 menit. Kebutuhan kecepatan internet atau bandwidth rata-rata dengan aplikasi Zoom sebesar 700 kbps, Skype sebesar 977 kbps, Hangouts sebesar 1100 kbps, dan Webex sebesar $1700 \mathrm{kbps}$, atau artinya dalam 1 menit membutuhkan data sebesar 42-66 kilobytes atau sekitar 2,5 sampai dengan 3,9 GB per jam (CNN Indonesia, 2020).

\section{Pembelajaran Asinkronus dengan Video Pembelajaran/ Video Tutorial}

Salah satu metode yang dapat ditempuh oleh Guru adalah dengan memberikan tayangan video atau menggunakan video dari YouTube, atau situs video lainnya untuk memberikan pengetahuan kepada peserta didik. Siswa diarahkan untuk menyimak Video melalui YouTube atau website tertentu. Siswa menyimak dengan menggunakan telepon pintar (smartphone) atau computer/ laptop yang dimiliki. Bahkan menggunakan YouTube untuk pertunjukan seni juga dapat memudahkan dalam proses pembelajaran daring. Integrasi teknologi informasi dalam pembelajaran dan mengajarkan seni pertunjukan dapat dilakukan menggunakan Youtube. Guru atau Dosen harus bisa mengimbangi kebutuhan generasi sekarang namun tetap menjaga nilai seni dan orisinalitas. Youtube dapat digunakan untuk meningkatkan pengetahuan dalam seni pertunjukan (DeWitt et al., 2013). Subjek dalam pembelajaran dengan video ini secara filosofis merupakan sajian berbasis keilmuan dan kognitif, yang disajikan dengan sentuhan humanisme.

\section{Penugasan Mandiri Terstruktur}

Penugasan mandiri dalam pembelajaran daring asinkronus menjadi pilihan untuk memberi pengalaman peserta didik dalam menganalisis permasalahan, menemukan hal baru, dan pengalaman dalam mencoba atau membuktikan teori. Penugasan lapangan secara mandiri, dalam bentuk observasi atau praktek lapangan, siswa akan melakukan tak teknis secara mandiri sesuai instruksi Guru. Penugasan mandiri terstruktur pada beberapa subyek mata pelajaran atau mata kuliah, misalnya: interaksi social, analisis bisnis atau mata pelajara/ mata kuliah lainnya, akan membuat siswa/ mahasiswa melakukan pembelajaran atau melaksanakan pendidikan non-formal atau pendidikan informal bersama teman, keluarga, kolega, tokoh masyarakat atau melalui interaksi komunitas.

Hal ini akan menstimulus respon siswa terhadap lingkungan yang dihadapi. Sejalan dengan ahli teori kognitif mempromosikan konsep bahwa pikiran memiliki peran penting dalam pembelajaran dan berusaha untuk fokus pada apa yang terjadi di antara terjadinya stimulus lingkungan dan respon siswa (Picciano, 2017). Temuan menunjukkan bahwa tingkat tugas terstruktur dapat berdampak pada sifat dan tingkat interaksi social yang terjadi, dan dengan kesimpulan terdapat peningkatan kognitif, ketika siswa bekerja sama secara kolaboratif. Aktivitas atau tugas preskriptif (dengan ketentuan) yang sangat terkontrol tampaknya membatasi keterlibatan dalam aspek prosedural praktek kerja (McGregor, 2008).

Kemampuan berfikir, analisis, dalam penugasan mandiri terstruktur menjadi kemampuan di ranah kognitif yang didasari oleh keilmuan tertentu yang dalam filsafat Pendidikan berada pada ranah akademik. Penugasan yang bersifat interaksi sosial akan melatih peserta didik untuk mengembangkan ranah humanisme. Dimana menurut 
Muhmidayeli (2011), sisi humanisme ini berperan dalam mengembangkan manusia dari segi keterampilan dan kehidupan secara praktek.

\section{Forum diskusi online}

Forum diskusi online dalam suatu mata kuliah dapat memiliki berbagai tujuan, dari menyediakan forum pembentukan ikatan sosial hingga memfasilitasi pembangunan pengetahuan baru (Holmes, 2005). Dengan forum diskusi, antar guru/ dosen dengan siswa/ mahasiswa, atau antar sesamanya dapat saling membuka topik pembicaraan, maupun merespon topik pembicaraan yang dibuat oleh guru/ dosen atau siswa/ mahasiswa lain atau saling bertukar informasi dan pengalaman, Dengan pengaturan yang sesuai, forum diskusi online juga dapat membantu meningkatkan berpikir kritis peserta didik, Ada tiga kategori utama yang secara langsung mendefinisikan peran kehadiran mengajar dalam mendukung pengembangan Critical Thinking siswa dalam sebuah diskusi online, daintaranya: merancang dan mengatur tugas diskusi, menyusun kegiatan diskusi, dan memberikan instruksi langsung selama proses diskusi (Foo \& Quek, 2019). Critical Thingking ini merupakan aspek kognitif yang merupakan ranah akademik dalam filsafat pendidikan. Adapun topik keilmuan yang terlibat dalam suatu forum diskusi merupakan ranah akademik. Sedangkan etika berkomunikasi dan berdiskusi mengambil tempat di ranah humanisme dalam teori Filsafat Pendidikan.

\section{Online Chat}

Online chat seperti WhatsApp, Telegram, Kaizala, dan sebagainya dapat dimanfaatkan untuk pembelajaran secara daring. Chat bersifat realtime yang dapat langsung dibaca oleh penerima, dan pada dasarnya bersifat sinkronus, namun hanya berupa tulisan dan atau gambar. Sebagian besar teknologi online chat memungkinkan interaksi dalam grup, seperti WhatsApp Group, Telegram Group, Kaizala Group, dan sebagainya. Dalam grup tersebut, sesame anggota grup dapat saling merespon chat satu sama lain.

Pemanfaatan sarana ini populer digunakan oleh Dosen dan Mahasiswa, atau Guru dengan Siswa, Guru dengan Orang Tua Siswa. Karena sifatnya yang realtime sinkronus, sehingga chat ini dianggap sarana komunikasi utama yang efektif digunakan. Bahkan aplikasi WhatsApp telah memiliki fitur kirim dokumen baik berupa gambar, suara, video, bahkan berkas tipe tertentu, semisal tugas siswa/ mahasiswa, atau soal dari guru atau dosen (WhatsApp Inc., 2020).

Secara filosofis, sarana online chat untuk pembelajaran dapat dimanfaatkan untuk mengembangkan sisi akademik yakni kognitif dan keilmuan, sekaligus memberikan keterampilan dalam interaksi dalam kehidupan dalam hal berkomunikasi yang baik dan benar.

\section{Peran Filsafat Pendidikan dalam Pembelajaran Daring}

Maksud dan tujuan dari Pendidikan adalah sama, sedangkan dalam pembelajaran daring yang berbeda hanyalah sarananya. Pembelajaran daring memungkinkan pembelajaran dilaksanakan tanpa melihat ruang dan waktu. Artinya secara filosofis, pembelajaran daring memiliki tujuan dan maksud yang sama, yaitu transformasi pengetahuan, informasi, dan pengalaman belajar. Sebagaimana diungkapkan oleh Muhmidayeli (2011), bahwa Filsafat pendidikan berperan dalam menganalisis dan mengkritisi aspek akademik dan humanis untuk sebuah pendidikan yang utuh dan seimbang. Filsafat pendidikan akan terus melakukan peninjauan terhadap proses pendidikan demi perkembangan pendidikan yang mampu mencetak manusia yang handal.

Pembelajaran daring secara folosofis, merupakan solusi atas permasalahan yang 
terjadi di tengah Pandemi Covid-19 ini. Karena situasi pandemi, perlu kajian hubungan antara Lembaga Pendidikan dengan tatanan masyarakat baru (new normal) dengan situasi yang mengharuskan masyarakat menjaga jarak (phsycal distancing) dan menjaga jarak hubungan sosial (social distancing). Hubungan tersebut menjadi salah satu objek dalam kajian filsafat pendidikan, termasuk metode dan strategi pembelajaran yang sesuai dengan kondisi peserta didik (Muhmidayeli, 2011). Dimana dalam situasi pembelajaran daring, kebijakan, maupun strategi pembelajaran hendaknya disesuaikan dengan kondisi peserta didik, apakah memiliki sarana, kuota internet, tersedianya jaringan dan faktor pendukung teknis lainnya.

\section{PENUTUP}

Kajian mengenai Filsafat Pendidikan dalam hal pembelajaran dari pada masa pandemic covid-19 ini mencakup berbagai sarana pembelajaran daring serta metode dan strategi belajar yang digunakan, dilihat dari sisi folosofis mampu mengakomodir tujuan pembelajaran dan tujuan Pendidikan secara umum.. Pada prinsipnya berbagai sarana pembelajaran daring mampu menjawab atau memberi solusi atas permasalahan yang terjadi akibat penerepan sistem pembelajaran dari rumah yang ditetapkan oleh pemerintah dalam rangka pencegahan penularan wabah virus corona (covid-19).

Kajian mendalam dengan dukungan data survei perlu dilakukan untuk membuktikan teori-teori yang telah dikaji. Dengan dukungan data survey serta analisis mendalam, diharapkan asumsi dan kajian literatur dapat lebih valid dan akurat dalam membangun teori baru di kemudian hari.

\section{DAFTAR PUSTAKA}

CNN Indonesia. (2020). 4 Aplikasi Video Conference yang Irit dan Boros Data. CNN Indonesia. https://www.cnnindonesia.com/teknolo gi/20200330191529-185-488422/4aplikasi-video-conference-yang-iritdan-boros-data

DeWitt, D., Alias, N., Siraj, S., Yaakub, M. Y., Ayob, J., \& Ishak, R. (2013). The Potential of Youtube for Teaching and Learning in the Performing Arts. Procedia - Social and Behavioral Sciences, 103(November), 1118-1126. https://doi.org/10.1016/j.sbspro.2013.1 0.439

Direktorat, Kejuruan, M., Jenderal, D., \& Vokasi, P. (2020). Jilid 2 Panduan Praktis Pembelajaran SMK pada MKB.

Foo, S. Y., \& Quek, C. L. (2019). Developing student' critical thinking through asynchronous online discussions: A literature review. Malaysian Online Journal of Educational Technology, 7(2), 37-58.

Holmes, K. (2005). Analysis of asynchronous online discussion using the SOLO taxonomy. Australian Journal of Educational and Developmental Psychology, 5(January 2005).

Jagtap, P. (2016). Teachers role as facilitator in learning. Scholarly Research Journal, 3(17), 3903-3905.

Kemendikbud. (2020). Surat Edaran Sekretaris Jenderal No.15 Tahun 2020 Pedoman Pelaksanaan Belajar Dari Rumah Selama Darurat Bencana COVID-19 di Indonesia. Sekretariat Nasional SPAB (Satuan Pendidikan Aman Bencana), 15, 1-16.

Kementerian Pendidikan dan Kebudayaan Republik Indonesia. (2020). Surat Edaran Menteri Pendidikan dan Kebudayaan Republik Indonesia Nomor 35952/MPK.A/HK/2020. Mendikbud RI, 1-2. https://www.kemdikbud.go.id

Laal, M., \& Salamati, P. (2012). Lifelong learning; Why do we need it? Procedia 
- Social and Behavioral Sciences, 31(2011), 399-403. https://doi.org/10.1016/j.sbspro.2011.1 2.073

Lewin, D., \& Lundie, D. (2016). Philosophies of Digital Pedagogy. Studies in Philosophy and Education, 35(3), 235-240. https://doi.org/10.1007/s11217-0169514-7

McGregor, D. (2008). The influence of task structure on students' learning processes: Observations from case studies in secondary school science. Journal of Curriculum Studies, 40(4), 509-540.

https://doi.org/10.1080/0022027070181 3282

Picciano, A. G. (2017). Theories and frameworks for online education: Seeking an integrated model. Online Learning Journal, 21(3), 166-190. https://doi.org/10.24059/olj.v21i3.1225

Siegel, Harvey, D.C. Phillips, and E. C. (2018). Philosophy of Education. The Stanford Encyclopedia of Philosophy. https://plato.stanford.edu/entries/educat ion-philosophy/

Srivastava, T. K. (2014). Teacher as facilitator: A requisite during foundation years of medical curriculum. National Journal of Physiology, Pharmacy and Pharmacology, 4(3), 179-181. https://doi.org/10.5455/njppp.2014.4.27 0620141

Thomas, G. (2010). Facilitator, Teacher, or Leader? Managing Conflicting Roles in Outdoor Education. Journal of Experiential Education, 32(3), 239254.

https://doi.org/10.1177/1053825909032 00305

Tudor, S. L. (2013). Formal - Non-formal Informal in Education. Procedia Social and Behavioral Sciences, 76(April 2013), 821-826. https://doi.org/10.1016/j.sbspro.2013.0 4.213

WhatsApp Inc. (2020). Fitur, Whatsapp. WhatsApp Inc. https://www.whatsapp.com/features/ Wikipedia. (2020a). Konferensi Video. Wikipedia. https://id.wikipedia.org/wiki/Konferens i_video

Wikipedia. (2020b). Pendidikan sepanjang hayat. https://id.wikipedia.org/wiki/Pendidi kan_sepanjang_hayat\#: :text=Pembe lajaran Sepanjang Hayat juga dapat,hidup yang jelas dan terarah. 